\title{
PLASMID COMPOSITION AND VIRULENCE-ASSOCIATED FACTORS OF Yersinia pestis ISOLATES FROM A PLAGUE OUTBREAK AT THE PARAIBA STATE, BRAZIL (1)
}

\author{
Nilma Cintra LEAL (2), Alzira Maria Paiva de AIMFIDA (2), \& Luis Carlos de Souza FERREIRA (31
}

\section{SUMMARY}

Pathogenic Yersinia pestis isolates were collected during a plague outbreak at the Paraiba State in 1986. The Y. pestis isolates were investigated for the presence of virulence-associated factors and plasmid content. All strains analysed were proficient in the expression of the VW and fraction 1 antigens, pigment adsorption and pesticin-fibronolysin-coagulase production. A similar plasmid profile composed by four plasmid with molecular weight of $60,44,14.9$, and 6.4 Megadaltons (MD) was found in all strains. DNA cleavage with EcoRI restriction enzyme further demonstrated the uniform plasmid content of the $\mathbf{Y}$. pestis isolates. Seven additional $\mathbf{Y}$. pestis strains, previously isolated in the same region but in an endemic state, showed the same plasmid fingerprint. The lack of any detectable difference between epidemic and endemic isolates as well as the value of plasmid fingerprints in epidemiology of $\mathbf{Y}$. pestis is discussed.

KEY WORDS: Yersinia pestis, plasmids, virulence-associated factors.

\section{INTRODUCTION}

When expressing its full virulence, Yersinia pestis. the causative agent of plague, is one of the most pathogenic organisms to the human being. The pathogenicity of $\mathbf{Y}$. pestis is determined by the expression of at least six different virulence factors: production of the $\mathrm{V}$ and $\mathrm{W}$ an ti gens ( $\mathrm{VWa}+$ ) and fraction 1 antigen ( $\mathrm{Fra}+$ ), synthesis of pesticin-fibrinolysin-coagulase ( $\mathrm{Pfc}+$ ), ability to adsorb exogenous pigments ( $\mathrm{Pgm}+)$, requirement for free calcium in growth medium at $37^{\circ} \mathrm{C}$; and autoagglutination (BEESLEY et al., 1967; BRUBAKER, 1979; BRUBAKER, 1972; LAIRD \& CAVANAUGH, 1980).
Several independent groups reported the in volvement of plasmids in the expression of the virulence factors of $Y$. pestis (BEN-GURION \& SHAFFERMAN, 1981; FERBER \& BRUBA KER, 1981; PORTNOY \& FALKOW, 1981: PORTNOY et al., 1983; PORTNOY \& MARTINEZ, 1985; TSUKANO et al., 1986). Production of the $\mathrm{V}$ and $\mathrm{W}$ antigens and $\mathrm{Ca}^{2+}$ requirement at $37^{\circ} \mathrm{C}$ are coded by a $42-48 \mathrm{Mdal}$ plasmid (BEN GURION \& SHAFFERMANN, 1981; FERBER \& BRUBAKER, 1981; PORTNOY \& FALKOW, 1981; PORTNOY et al., 1983). Production of pes. ticin and fraction 1 antigen are associated with

(1) Research supported by the Japanese International Cooperation Agency and the Brazilian National Research Council

(2) Centro de Pesquisas Aggeu Magalhàes. Fundaçāo Oswaldo Cruz. Recife, Pernambuco, Brazil.

(3) Laboratório de Imunopatologia Keizo Asami and Departamento de Biofísica c Radiobiologia. Recife, Pernambuco, Brazil. Address for correspondence: Dr. L. C. S. Ferreira. Laboratório de Imunopatologia Keizo Asami, Universidade Federal de Pernam buco. Cidade Universitária. 50739 Recife, Pernambuco, Brazil. 
LEAL, N. C.; ALMEIDA, A. M. P. de \& FERREIRA, L. C. de S. - Plasmid composition and virulence associated factors of Yersinia pestis isolates from a plague outbreak at the Paraiba State, Brazil. Rev. Inst. Med. trop. S. Paulo, 31(5): 295 300. 1989.

a 6.7 Mdal and a 12-20 Mdal plasmids, respectively (FERBER \& BRUBAKER, 1981; TSUKANO et al., 1986). Genetic evidences demonstrated that the $\mathrm{Pgm}+$ character is also coded by a plas mid even though it could never be isolated, pro bably due to its high molecular weight (TSUKANO et al., 1986).

\section{MATERIALS AND METHODS}

\section{Bacterial strains}

Y. pestis strains used in this work are listed in Table 1. Escherichia coli $39 \mathrm{R} 861$ was obtained at the National Collection Institute of Type Culture, Public Health Laboratory, Collin Dale, London.

\section{Growth conditions and media}

Strains were normally grown in liquid cultu res with agitation in YT medium $12 \%$ tryptone, $1 \%$ yeast extract, $1 \%$ sodium chloride) at $28^{\circ} \mathrm{C}$ during 24 hours. Media used for detection of virulence factors were described elsewhere $(\mathrm{BAH}$ MANYAR \& CAVANAUGH, 1976).

\section{Isolation of $\mathrm{Y}$. pestis from infected rodents or} humans and maintenance of bacterial stocks

Samples of $\mathbf{Y}$. pestis were recovered from spleen or blood (rodents) and from swollen limphonodes or wounds (humans) as described by ALMEIDA et al. (1989) according to BALTA. ZARD et al. (1956). Cultures were maintained at $4^{\prime \prime} \mathrm{C}$ in agar stabs.

\section{Detection of virulence-associated factors}

Virulence-associated factors were determined essentially as described by BAHMANYAR \& CAVANAUGH (1976). Pgm ${ }^{+}$cells grow as dark brown colonies on Congo-red agar at $28^{\circ} \mathrm{C}$ after 3 days. $\mathrm{Vwa}^{+}$cells were able to grow on magne sium oxalate agar at $28^{\circ} \mathrm{C}$ but not at $37^{\circ} \mathrm{C}$. Pro duction of fraction 1 antigen ( $\mathrm{Fra}^{+}$) was assayed by immunodiffusion on glass slides with polyclonal rabbit-anti $\mathrm{F} 1$ serum. The $\mathrm{Pcf}^{+}$character was evaluated by the coagulation of rabbit plasma at $26^{\circ} \mathrm{C}$ after mixing with $\mathbf{Y}$. pestis cells.

\section{DNA manipulation techniques}

Plasmid DNA were isolated according the method of CASSE et al. (1979) as modified by R. R. BRUBAKER (personal communication). Briefly, cells grown in liquid YT medium were centrifuged $(12.000 \mathrm{G}, 4 \mathrm{C}, 10 \mathrm{~min})$ and washed once with $50 \mathrm{mM}$ Tris-HCl, $10 \mathrm{mM}$ EDTA $\mathrm{pH}$ $8.0)$ buffer. Cell lysis was obtained after addition of the lysing mixture $(1 \%$ SDS, $50 \mathrm{mM}, 20 \mathrm{mM}$ EDTA-Na, pH 12.45, to the cell suspension. To improve cell lysis the mixture was incubated at $37 \mathrm{C}$ for $25 \mathrm{~min}$ and. then. $2 \mathrm{M}$ Tris $\mathrm{HCl}$ ( $\mathrm{pH} 7.0$ ) was added for neutralization followed by $5 \mathrm{M}$ $\mathrm{NaCl}$. After extraction with $3 \% \mathrm{NaCl}$-saturated phenol, the DNA was ethanol precipitated from the supernatant. An additional purification step upon cesium chloride gradient centrifugation was necessary for cleavage with restriction enzy mes.

Restriction endonuclease digestions were carried out under conditions described by MANIATIS et al. (1982). Cleaved and uncut plasmid DNA were subjected to electrophoresis in $5 \mathrm{~mm}$ thick horizontal $1 \%$ or $0.8 \%$ agarose gels, respectively, in Tris-acetate or Tris-borate (restriction fragments) buffers at $60 \mathrm{~V}$. Gels were stained with ethidium bromide and photographed under UV light illumination.

\section{RESULTS}

Isolation of $Y$. pestis strains and detection of virulence-associated factors

Y. pestis is endemic at the Paraiba State since its introduction in to the continent at the end of the nineteenth century. Since that time sporadic small epidemic plague outbreaks are registered in this region roughly at every ten years. During the spring of 1986 , after a quiescent period of more than 10 years, a plague outbreak bursted at the Paraiba State spreading over se. veral counties and causing five deaths and $\mathbf{4 8}$ serological confirmed infected persons (ALMEI DA et al., 1989).

A total of 19 Y. pestis samples were obtained from rodents ( 16 strains) and humans (3 strains) during the epidemic outbreak. These strains were investigated in relation to the expression 
LEAL, N. C.; ALMEIDA. A. M. P. de \& FERREIRA. L. C de S. - Plasmid composition and virulence associated factors of Yersinia pestis isolates from a plague outbreak at the Paraiba State. Brazil. Rev. Inst. Med. trop. S. Paulo, 31(5): 295 300, 1989.

of the virulence-associated factors: production of fraction 1 antigen and coagulase, pigmenta. tion and calcium dependence were assayed in each of the Y. pestis samples isolated. All strains proved to be proficient in all virulence-associa. ted factors tested (Table 1 ).

Seven Y. pestis strains previously isolated from rodents in the same area, but in endemic conditions, were analysed for comparison purposes. Table 1 shows that these strains exhibit the same pattern of virulence-associated factors dis played by the epidemic isolates.

\section{Plasmid content of the $Y$. pestis strains}

Plasmid DNA of all $26 \mathrm{Y}$. pestis strains were isolated and compared after electrophoresis on agarose gels. All strains harbored a similar four plasmid set with molecular weigh ts of $60,44,14.9$ and $6.4 \mathrm{Mdal}$ in spite of differences in the isola tion periods, mammalian host and infection sta tus, i. e.. endemic or epidemic conditions (Figure 1).

To further evaluate the homology among the plasmid DNA of the several Y. pestis isolates,

TABLE 1

Yersinia pestis strains analysed and detection of virulence associated factors.

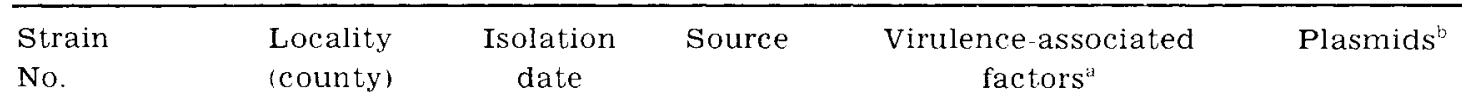

Fra ${ }^{\circ}$ Vwa ${ }^{+} \operatorname{Pcf}^{+} \operatorname{Pgm}^{+}$

\begin{tabular}{|c|c|c|c|c|c|c|c|c|}
\hline 810 & Natuba & 1979 & Rodent & + & + & + & + & + \\
\hline 811 & Natuba & 1979 & Rodent & + & + & + & + & + \\
\hline 817 & Natuba & 1979 & Rodent & + & + & + & + & + \\
\hline 820 & Natuba & 1979 & Rodent & + & + & + & + & + \\
\hline 843 & Natuba & 1980 & Rodent & + & + & + & + & + \\
\hline 851 & Natuba & 1980 & Rodent & + & + & + & + & + \\
\hline 860 & S. S. Félix & 1982 & Rodent & + & + & + & + & + \\
\hline 862 & Solânea & 1986 & Human & + & + & + & + & + \\
\hline 863 & B. S. Rosa & 1986 & Human & + & + & + & + & + \\
\hline 864 & Solânea & 1986 & Rodent & + & + & + & + & + \\
\hline 865 & Solânea & 1986 & Rodent & + & + & + & + & + \\
\hline 866 & Solânea & 1986 & Rodent & + & + & + & + & + \\
\hline 867 & Solânea & 1986 & Rodent & + & + & + & + & + \\
\hline 868 & Solánea & 1986 & Rodent & + & + & + & + & + \\
\hline 869 & Solánea & 1986 & Rodent & + & + & + & + & + \\
\hline 870 & Solânea & 1986 & Rodent & + & + & + & + & + \\
\hline 871 & Solânea & 1986 & Rodent & + & + & + & + & + \\
\hline 872 & Solânea & 1986 & Rodent & + & + & + & + & + \\
\hline 873 & Solânea & 1986 & Rodent & + & + & + & + & + \\
\hline 875 & Solànea & 1986 & Rodent & + & + & + & + & + \\
\hline 876 & Solànea & 1986 & Rodent & + & + & + & + & + \\
\hline 877 & Solánea & 1986 & Rodent & + & + & + & + & + \\
\hline 878 & Solànea & 1986 & Rodent & + & + & + & + & + \\
\hline 879 & Solânea & 1986 & Rodent & + & + & + & + & + \\
\hline 880 & Solânea & 1986 & Rodent & + & + & + & + & + \\
\hline 881 & Remígio & 1986 & Human & + & + & + & + & + \\
\hline
\end{tabular}

$\mathrm{a}-\mathrm{Fra}^{+}$- production of the $\mathrm{F} 1$ antigen; Vwa ${ }^{+}$- production of the $\mathrm{V}$ and $\mathrm{W}$ antigens; Pcf- synthesis of pesticin, fibrinolysin, coagulase; Pgm ' - ability to adsorb exogenous pigments.

$\mathrm{b}$ - plasmids found: $60.44,14.9$, and $6.4 \mathrm{MD}$. 
LEAL, N. C.; ALMEIDA, A. M. P. de \& FERREIRA, L. C. de S. - Plasmid composition and virulence associated factors of Yersinia pestis isolates from a plague outbreak at the Paraiba State, Brazil. Rev. Inst. Med. trop. S. Paulo, 31(5): 295300,1989

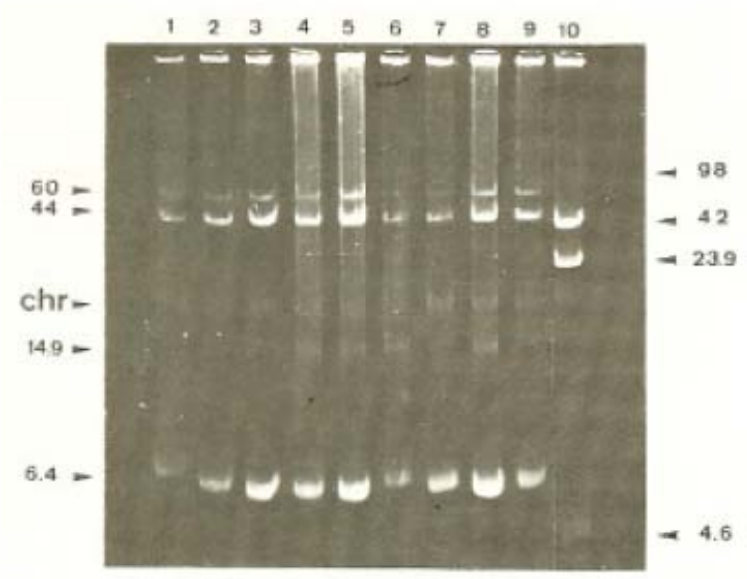

Fig. 1 - Agarose gel electrophoresis of plasmid DNA from Y. pestis isolates, 1 - strain 810 ; 2 - strain g11: 3 - strain 817: 4 - strain 862; 5 - strain $863 ; 6$ - strain 881: 7 - strain 864: 8 - strain 871: 9 - strain 874: 10 - E. coli 39R861. Mole cular weight marker plasmids of $\mathbf{E}$. coli $39 \mathrm{R} 8 \mathrm{~s} 1$ are indicated on the right.

restriction endonuclease reactions of the total plasmid DNA content were carried out with all samples. Figure 2 shows the result of the clea. vage reaction with plasmid DNA of some representative strains. EcoRI cleaved plasmid DNA of the $Y$. pestis strains resulted in a common fragment profile. These results suggest that the Y. pestis isolates from the plague outbreak at

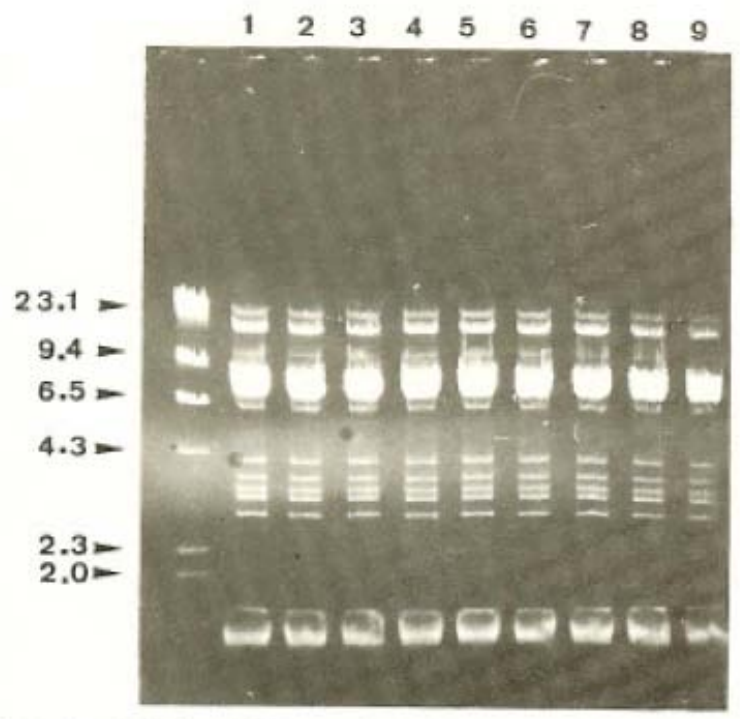

Flg. 2 - EcoRI restriction endonuclease digestion pattern of plasmid DNA isolated from $\mathbf{Y}$, pestis strains. $1-810 ; 2-$ B11: $3-817: 4-862 ; 5-863 ; 6$ - 881: 7 - 864:8-871; 9 - 874. Phage lambda DNA digested with Hind III was used as molecular weight marker and is indicated on the left. the Paraiba State were quite uniform in terms of their plasmid DNA content.

\section{DISCUSSION}

The analysis of plasmid content as a tool in the epidemiology of bacteria has received in creasing attention from researches in recent vears IMAYER, 1988 . In several cases it was possible to elucidate the origin of specific out breaks or to trace the dispersal routes of certain strains by comparing plasmids or restriction fragment profiles as, for example. in Salmonella, Escherichia coli, and Neisseria gonorrhoea (BRUNER et al., 1983; TIETZE \& TSCHAPE, 1983; YEUNG et al., 1986).

Analysis of plasmid fingerprints as an ap. proach to the epidemiology of Yersinia was mainly restricted to the virulence plasmid of $\mathbf{Y}$. enterocolitica and $Y$.pseudotuberculosis I ISHI GURO et al., 1985; WARTENBERG et al., 1988). Even though a clear molecular relatedness exists among the calcium-dependence coding plasmids of Yersinia, nothing is known about the potential use of the $Y$. pestis specific plasmids as epidemiological markers (PORTNOY \& FALKOW, 1981; PORTNOY \& MARTINEZ, 1985). The small differences in the reported mole cular weights of plasmids coding for virulence. associated genes in $\mathbf{Y}$. pestis could suggest a possible diversity among isolates from different places or periods (PORTNOY et al, 1983; FEBER \& BRUBAKER. 1981; TSUKANO el al.. 1986 1.

Our results demonstrated a uniform expres sion of virulence associated factors and similar plasmids in Y. pestis samples obtained at different places, periods and mammalian hosts. The identical EcoRI restriction pattern confirmed the probable identity of the plasmidial content in these isolates. Such results would indicate a probable common origin of the $\mathbf{Y}$. pest is strains established at the Paraiba State, which is part of a broader plague focus represented by the Borborema plateau (ALMEIDA et al., 1985: ALMEI DA et al., 1981).

The identical plamid profile and virulence. associated factors in the $\mathbf{Y}$.pestis samples isolated in endemic or epidemic conditions would 
LEAL, N. C.: ALMEIDA. A. M. P. de \& FERREIRA, L. C. de S. - Plasmid composition and virulence associated factors of Yersinia pestis isolates from a plague outbreak at the Paraiba State, Brazil. Rev. Inst. Med. trop. S. Paulo, 31(5): 295300,1989

suggest that epidemic isolates have no plasmid - associated special feature providing them with an increased virulence.

Thus, it is conceivable that the rise of a pla gue outbreak is probably more related to dete rioration of sanitation conditions or to ecological alterations. which would result in unusual in creases in the flea or rat populations. rather than to the selection of strain expressing higher viru lence.

Plague is a serious public health concern in Brazil. Several active endemic focuses are still present in the Northeast region of the country where health conditions and sanitation are worsening due to uncontrolled population growth and low incomes. The molecular characteriza. tion of $\mathbf{Y}$. pestis strains in this region could give significant contributions to the identification of specially pathogenic strains or to elucidate dis persal routes of future epidemic outbreaks. The analysis of $\mathbf{Y}$. pestis isolates from different pla gue focuses in Brazil is under investigation in our laboratory.

\section{RESUMO}

\section{Composição plasmidial e fatores associados à virulência em cepas de Yersinia pestis de um surto de peste no Estado da Paraiba, Brasil.}

Cepas patogenicas de Yersinia pesíis foram coletadas durante tum surto de peste no Estado da Paraiba em 1986. Os isolados de $Y$. pestis foram analisados quanto a presença de fatores associados à virulencia e conteudo plasmidial Todas as linhagens analisadas foram proficien tes na expressão dos antígenos VW e fração 1. além de possuirem capacidade de adsorçáo de pigmentos e produçāo de pesticina fibrinolisina coagulase. Um perfil plasmidial semelhante composto por quatro plasmideos com peso mo lecular de $60,44,14.9$. e $6.4 \mathrm{MD}$ foi encontrado em todas as linhagens. A clivagem do DNA plas midial com a enzima de restriçào EcoRI demonstrou o conteúdo plasmidial uniforme dos isola dos de Y. pestis. Sete outras linhagens de $\mathbf{Y}$. pestis, isoladas previamente no mesmo local mas em condição endêmicá, mostraram o mes mo perfil plasmidial. A falta de diferenças entre os isolados epidêmicos e endêmicos assim como o uso do perfil plasmidial na epidemiologia de Y. pestis é discutida.

\section{ACKNOWLEDGMENTS}

We are greatly indebted to Dr. R. Brubaker for the important advises on plasmid isolation procedure and to Mr. S. H. Almeida and Mrs $\mathrm{Y}$. Nakasawa for helpful technical assistance.

\section{REFERENCES}

1. ALMEIDA C.R. ALMEIDA, A M. P: VIEIRA. I. B GUIDA, J \& BUTLER, T. -.. Plague in Brazil during Lw vears of bacteriological and serologieal surveillance Bull. Wld. Hith. Org., $5^{\text {e. }}=597.1981$

2. ALMEIDA. A. M. P.; BRASIL, D. P. CARVALHO, F. \& WLMEIDA, C. R. Isolumento de Yersinia pestis nos foros pestosus do Nordeste do Brasil no periodo de 1956 a 1982 Rev. Inst. Med, trop. S. Paulo, 27: 207218.1985.

3. MLMEIDA. A. M. P : BRASIL. D P. LEAL. N. C $\therefore$ MELO M. E. B.. REGO.R V \& ALMEIDA.C.R. . Estudos bacteriologicos e sorológicos de um surto de peste no est:i do da Paraiba. Brasil Mem. Inst. Oswaldo Cruz, 1989 in press

4. BAHMANYAR, M. \& CAVANALGH, D. C. . Plague manual. Geneve. World Health Organization. 1976

5. BALTAZARD, M.: DAVIS. D. Fi. S.: DEVIGNAT, R: GI RAFD. G.: GOHAR. M. A.; KARTMAN. L.: MEYER.K F.: PARKER. M. T.: POLLITZER. R.: PRINCE. F'. M QUAN.S F \& WAGLE.P - Recommended laboratur. nie thods for the diagnosis of plague Bull. Wld. Hlth. Orf. 14: 457509.1956

6. BEESLEY E. D. BRUBAKER, R. R. JANSSEN, W A \& SLRGALLA. H. J. Pesticins. III Expression of coagulase and mechanism of fibrinolysis. J. Bact.. 94 $1926 \quad 1967$

7 BEN GURION, R. ¿ SHAFFERMAN,A. - Essential viru ience determinants of different Yersinia species are car ried on a common plasmid. Plasmid. 5: 183187.1981

8. BRUBAKER.R.R. - Expression of virulence in Yersinia In: SHELESSINGER, D. ed Microbiology. New York. American Society for Microbiology. 1979. p. 168.171

9. BRUBAKFR. R. R -- The genus Yersinia: biochemistry and geneties of virulence Curr. Top. Microbiol. Immunol. 5i: 111158,1972

10. BRUNNER, F : MARGADANT, A.: PEDUZZI, R \& PIF FARETTI. J C. - The plasmid pattern as an epidemio logic tool for Salmonella typhimurium epidemies: compa rison with the lysotype. J. infect. Dis., 148: 7:11, 1983.

11. CASSE, F : BOUCHER, C: JULLIOT, J, S: MICHEL. M \& DENAIRE. J. - Identification and characterization of 
LEAL. N. C.: ALMFIDA, A. M. P. de \& FERREIRA, L. C. de S. - Plasmid composition and virulence associated factors of Yersinia pestis isolates from a plague outbreak at the Paraiba State. Brazil Rev. Inst. Med. trop. S. Paulo, 31(5): 295300,1989

large plasmids in Rhizobium melillot using agarose grel electrophoresis. J. gen. Microbiol., 113: 229 242. 197 !

12. FERBER, I M. \& BRUEAKER, R, R. - Plasmids in Yersinia pestis. Infect. Immun., 31: 839841.1981

13. ISHIGURO, N. NAKAOKA, $¥$ SATO G. \& TSUBOKA. M. - Plasmid DNA relatedness among different sero groups of Yersinia pseudotuberculosis. J.clin. Microbiol., 21: 602665,1985

14. LAIRD. W, J. \& CAVANAUGH, D. C, ... Correlation of autoagglutination and virulence of Yersinia. J. clin. Microbiol., 11: 430432.1980

15. MANIATIS T. FRITSCH, E. F. \& SAMBROOK, J Molecular cloning. A laboratory manual. New York, Cold Spring Harbor Laboratory. Cold Spring Harbor, 1982

16. MAYER, L. W, - Use of plasmid profiles in epidemiologic survaillance of disease outbreaks and in tracing the trans mission of antibiotic resistance. Clin. Microbiol. Rev., 1 : 228243,1988

17. PORTNOY.D. A.\& FALKOW.S. - Virulence associated plasmids from Yersinia enterocolitica and Yersinia pes. tis. J. Bact., 148: 877883.1981
18. PORTNOY, D. A.: BLANK, H. F : KINGSBURY. D. T \& FALKOW, S. - Genetic analysis of essential plasmid determinants of pathogenieity in Yersinia pestis. J. infect. Dis., 148: 297304,1983

19. PORTNOY. D. A. \& MARTINEZ R. J - Role of a plas mid in the pathogenicity of Yersinia species Curr. Top. Microbiol. Immunol., 118: 29 51, 1985.

20. TIETZE. E. \& TSCHAPE, H -- Plasmid pattem analysis of natural bacterial isolates and its epidemiolocical impli ration. J. Hyg. (Lond.). 90: 475488.1983

21. TSUKANO. H. WAKE, A. \& SAKAKIBARA. Y. -- Pla nid like properties of the four virulenee associtod fartors of Yersinia pestis. Microbiol. Immunol., 30: 837848.1986

22. WARTENBERG, K : WENINGER.J.\& ROLLINGHORF M. -- Plasmids of Yersinia enterocolitica and Yersinia pseudotuberculosis: analysis with restriction endonu clcases, Zbl. Bakt. Mikrobiol. Hyg., 268A: 213219,1988

23. YEUNG, K. H.: DILLON, J. R.; PAUZE, M.\& WALLACE E.-A novel 4.9 kilobase plasmid assoriatod with an out break of penicillinase ploducing Neisseria gonorrhoeac J. infect Dis., 153: 11621165,1986 Recobido para publicacao en 121989 